\title{
Chest Imaging Findings in Hospitalized Children with $\mathrm{H}_{1} \mathrm{~N}_{1}$ Influenza
}

\author{
Sevgi Pekcan, Bahar Göktürk², Şükrü Nail Güner ${ }^{3}$, Kemal Ödev $^{4}$, İsmail Reisli ${ }^{3}$
}

${ }^{1}$ Department of Pediatrics, Division Pediatric Pulmonology, Necmettin Erbakan University Meram Faculty of Medicine, Konya ${ }^{2}$ Department of Pediatrics, Division Children Allergy and Immunology, Konya Training and Research Hospital, Konya ${ }^{3}$ Department of Pediatrics, Division Children Allergy and Immunology, Necmettin Erbakan University Meram Faculty of Medicine, Konya

${ }^{4}$ Department of Radiology, Necmettin Erbakan University Meram Faculty of Medicine, Konya

\begin{abstract}
Objective: The aim was to review the radiological findings and to find new prognostic factors that determine the need for pediatric intensive care unit (PICU) in children with swine-origin influenza $(\mathrm{HlNl})$ virus infection.

Methods: Chest X-ray (CXR) and computed tomography (CT) findings of 18 children with laboratory-confirmed H1Nl infection ( 9 boys, 9 girls) with a median age of 34 (1-216) months were retrospectively evaluated.

Results: CXRs were performed in $15(83.3 \%)$ and thorax CT in 7 (38.8\%) children. Abnormal findings were detected in $60 \%$ of the patients who underwent CXR and $85.7 \%$ of the patients who underwent thorax CT. Radiological findings were mostly diffuse, bilateral, and asymmetric. Ground-glass opacity (GGO) (66.6\%) was the leading abnormality and was followed by reticulation (38.8\%), nodules (27.7\%), consolidation only (16.6\%), tree-in-bud pattern (11.1\%), consolidation with GGO (5.5\%), and septal lines (5.5\%). Lymphadenopathy (22.2\%), air trapping (5.5\%), and parenchymal band (5.5\%) were other recorded findings. CXR was found to be insufficient to detect subpleural nodules, lymphadenopathies, and sometimes GGO. Only existence of nodules $(\mathrm{p}=0.04)$ affected the need for PICU admission.
\end{abstract}

Conclusion: The most common radiological findings in children with HINl infection were bilateral, asymmetric GGO with or without associated multifocal areas of consolidation. CXR was insufficient to detect subpleural nodules, lymphadenopathies, and sometimes GGO. The existence of nodules is a bad prognostic factor in determining the need for PICU admission.

Keywords: Chest imaging, children, HlNl influenza, prognostic factors

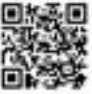

Received Date: 16.08.2014

Accepted Date: 05.01.2015

Available Online Date: 27.02.2015

Address for correspondence

Bahar Göktürk, Department of Pediatrics, Division Children Allergy and Immunology, Konya Training and Research Hospital, Konya, Turkey E-mail: gokturkbahar@yahoo.com (1) \& ${ }_{\text {Commons Attribution-NonCommercia }}^{\text {This work is licensed under a Creative }}$ 4.0 International License.

DOI: $10.5152 /$ ejp.2015.22931

- Available online at www.eurasianjpulmonol.com

\section{INTRODUCTION}

Novel swine-origin influenza A (2009 H1N1) was first reported in Mexico in April 2009 (1). Since then, it has rapidly spread to many countries around the world. The first laboratory-confirmed case in Turkey was seen on June 27, 2009, and the pandemic 2009 H1N1 influenza A virus arrived at Konya in September 2009 (2). The symptoms of H1N1 infection may be similar to seasonal influenza, and hospitalization is not usually required. The virus can infect the lower respiratory tract and cause rapidly progressive pneumonia, especially in children and younger adults. The abnormal thoracic computed tomography (CT) scan findings vary widely among the studies of $2009 \mathrm{H} 1 \mathrm{~N} 1$ influenza. Descriptions of the chest imaging manifestations of $\mathrm{H} 1 \mathrm{~N} 1$ virus infection in children are limited (3-7).

This study aimed to describe chest X-ray (CXR) and thorax computed tomography (CT) findings of children with confirmed pandemic 2009 influenza A (H1N1) infection, to review the radiological findings, and to find new prognostic factors that determine the need for pediatric intensive care unit (PICU) in children hospitalized with swine-origin influenza (H1N1) virus infection.

\section{METHODS}

Data were collected from 18 children under 18 years of age and who were hospitalized at the pediatric departments of Necmettin Erbakan University Meram Medical Faculty, a tertiary hospital, between October 31, 2009 and December 24, 2009 with the criteria for pandemic influenza A in- 
fection according to the World Health Organization (WHO) (8) and who underwent radiological examinations. For confirmation of 2009 pandemic H1N1, nasopharyngeal swabs were sent to the National Influenza Reference Laboratory at Ankara Hıfzı Sıha Institutue in a viral transport medium and were tested with a reverse-transcriptase polymerase chain reaction (RT-PCR) assay. The study was approved by the Institutional Review Board at Necmettin Erbakan University Meram Medical Faculty. All study participants were required to sign an informed consent form, and those who did not were excluded from the study.

Clinical and laboratory data were extracted from files and electronic medical records. Age at diagnosis, sex, complaints at admission, underlying disorders that were considered as risk factors for severe influenza, respiratory complications (rales, rhonchi, dyspnea, hypoxia, wheezing, pneumothorax, pneumomediastinum), duration of hospitalization, necessity for PICU management, and mechanical ventilation (MV) were recorded.

Fifteen patients were studied by CXR and 7 patients by CT. Chest CT was performed in patients with discordance between the symptoms and the plain radiography appearance, progression of dyspnea despite stable radiographic findings, or the presence of an air-leak complication visible on plain radiography. Posteroanterior radiographs were performed (Multix unit; Siemens, Erlangen, Germany). A technique of $60 \mathrm{kV}, 4 \mathrm{mAs}$, and $180-\mathrm{cm}$ film-focus distance was used for the posteroanterior-projection radiographs. Bedside anteroposterior projection, radiographs were obtained with a mobile unit (AMX 4; GE Healthcare, USA) using a $60 \mathrm{kV}, 4 \mathrm{mAs}$, and a 100-cm film-focus distance. Thorax CT was performed in 15 patients. The studies were performed on a 64-MDCT (multi-detector CT) scanner (Somatom Sensation; Siemens, Erlangen, Germany). The protocol used was as follows: end-inspiratory acquisition, $100 \mathrm{kV}, 150-200 \mathrm{mAs}$, and 1-mm reformation. The images were viewed on both lungs (window width, 1,500 HU; level, $-700 \mathrm{HU}$ ) and mediastinal (window width, $350 \mathrm{HU}$; level, $40 \mathrm{HU}$ ) settings. All CT examinations were performed without the use of contrast material. The radiological data were reviewed by a consensus between a radiologist and a pediatric pulmonologist with at least 15 years of experience in pulmonary imaging. All images were reviewed on a picture archiving and communication system.

Radiological findings were characterized by the type and pattern of opacities and zonal distribution. The findings were classified as normal or abnormal on the basis of an assessment of the lung parenchyma, airways, pleura, hila, and mediastinum. Abnormalities were further characterized as consolidation (homogeneous opacification of the parenchyma obscuring the underlying vessels), GGO (increased attenuation without obscuring the underlying vessels or hazy areas of increased opacity), nodules (focal rounded opacities measuring $<3 \mathrm{~cm}$ in diameter), tree-in-bud pattern, septal lines, and reticulation (linear opacities forming a meshlike pattern). Any additional lung finding was recorded.

The lung involvement was characterized as unilateral or bilateral. If the involvement was deemed bilateral, the process was categorized as symmetric or asymmetric in nature. The distribution was also categorized as focal, multifocal, and diffuse. Focal was defined as a single focus of abnormality, multifocal as more than one focus, and diffuse as involving the volume of at least one lung and continuous involvement without respect to lung segments.
Predominant distribution was assessed as being in the upper, middle, or lower lung zone. The upper zone was defined as the area above the level of the carina, the middle zone as the area between the level of the carina and the level of infrapulmonary vein, and the lower zone as the area below the level of infrapulmonary vein. Peripheral (subpleural; involving mainly the peripheral one-third of the lung), central (peribronchovascular), or random (without predilection for subpleural or central regions) location of lesions was also recorded.

The presence of associated hilar, paratracheal, or mediastinal LAPs, pleural abnormalities, volume loss, bronchiolar and/or bronchial dilatation, pulmonary interstitial emphysema, pneumomediastinum, pneumothorax, pericardial pleural effusion, air trapping, and cysts was also assessed. A lymph node was considered enlarged when the short-axis diameter was $>1 \mathrm{~cm}$ at the hilum, mediastinum, paratracheal region, and any other sites. The presence of parenchymal bands, irregular bronchovascular, pleural, or mediastinal interfaces, and traction bronchiectasis was considered evidence of probable fibrosis. Effects of radiological findings on hypoxia, hospitalization periods, need for PICU admission, and prognosis were evaluated.

\section{Statistical Analysis}

Statistical analysis was done using SPSS version 16.0 software (SPSS Inc., Chicago, IL, USA). Data were presented as numbers (percentages), mean \pm standard deviation (SD), or median (range) as appropriate. Categorical variables were compared using the Chi-square test or Fisher's exact test, and continuous variables were compared using the Mann-Whitney $U$ test.

\section{RESULTS}

Eighteen patients with confirmed diagnosis of 2009 H1N1 influenza virus infection were evaluated by radiological imagings. Half of the patients were females. The median age of patients was 34 (1-216) months (Table 1). The main symptoms were high fever (94\%), cough $(83 \%)$, and fatigue $(50 \%)$. The main signs were rales $(55.5 \%)$, hypoxemia (50\%), and pharyngitis/tonsillitis (33.3\%) (Table 2). The median time interval between radiological imaging and symptom onset was 1 day (1-2) for CXR and 6 days (1-16 days) for CT examination (Table 3). Hypoxia was noted in half the children, and the frequency did not change according to ages $(p=0.055)$. A 10-month old girl, who was admitted with encephalopathy, died. Seventeen patients were discharged without residual symptoms. Seven of the patients (38.8\%) needed PICU, and only 1 of them (the patient who died) needed MV. Twelve children (66.6\%) had 1 or more underlying disorders (Table 3 ). While half of the patients who had an underlying disorder had hypoxia, $40 \%$ of the patients who did not have underlying disorder had hypoxia $(p=0.64)$.

CXRs were performed in 15 (83.3\%) and thorax CT in 7 (38.8\%) children. Four patients $(22.2 \%)$ had both the radiological imagings, but 2 of them did not have any abnormalities on CXR [median performance time was 1.5 days (1-2)] and had abnormalities on thorax CT [median performance time was 8 (7-9) days]. Abnormal findings were detected in 9 (60\%) patients who underwent CXR and 6 (85.7\%) patients who underwent thorax CT. CXRs were performed on median first (1-2) day, and thorax CTs were performed on median sixth (1-16) day of hospitalization.

The radiological data of the patients were evaluated together by a radiologist and a pediatric pulmonologist. Thirteen $(72.2 \%)$ had bilateral (2 symmetric, 11 asymmetric) findings and 1 (5.5\%) had uni- 
Table 1. Patient characteristics and medical backgrounds of children with H1N1 infection

\begin{tabular}{|c|c|}
\hline Characteristic & Data \\
\hline Sex: $M / F,(n)$ & $9 / 9$ \\
\hline Median age (months)* & $34(1-216)$ \\
\hline Underlying comorbid condition, n (\%) & $12(66.6)$ \\
\hline Influenza encephalopathy, n (\%) & $1(5.5)$ \\
\hline Duration of hospitalization (days)* & $5(1-20)$ \\
\hline Duration from onset to CXR (days)* & $1(1-2)$ \\
\hline Duration from onset to thorax CT (days)* & $6(1-16)$ \\
\hline Need of mechanical ventilation, $\mathrm{n}(\%)$ & $1(5.5)$ \\
\hline Need of intensive care unit, $\mathrm{n}(\%)$ & $4(22.2)$ \\
\hline Fatal outcome, n (\%) & $1(5.5)$ \\
\hline \multicolumn{2}{|c|}{$\begin{array}{l}\text { *: Median (minimum-maximum), CT: Computed tomography, CXR: ches } \\
\text { X-ray, F: female, M: male, n: number }\end{array}$} \\
\hline
\end{tabular}

Table 2. Clinical symptoms and signs of patients with H1N1 influenza

\begin{tabular}{|l|l|}
\hline Symptoms & $(\%)$ \\
\hline Fever & 94.4 \\
Hypoxia & 83.3 \\
Rale & 50.0 \\
Fatigue & 55.5 \\
Vomiting & 33.3 \\
\hline Difficulty in breathing & 33.3 \\
Pharyngitis (tonsillitis) & 33.3 \\
\hline Throat ache & 33.3 \\
Diarrhea & 22.2 \\
Wheezing & 22.2 \\
\hline Dehydration & 16.6 \\
\hline Running nose (nasal obstruction) & 16.6 \\
\hline Rhonchi & 11.1 \\
\hline Myalgia & 11.1 \\
Change in the level of consciousness & 11.1 \\
\hline
\end{tabular}

lateral. The distribution of lesions was diffuse in 12 (66.6\%) patients and multifocal in 5 (27.7\%). Predominant distribution was at all zones in $9(50 \%)$ patients and at both middle and lower zones in $5(27.7 \%)$. The location of lesions was random in 8 (44.4\%) patients, central dominant in 5 (27.7\%), and peripheral dominant in 1 (5.5\%). GGO (66.6\%) was the leading abnormality, which was followed by reticulation (38.8\%), nodules (27.7\%), consolidation only (16.6\%), treein-bud pattern (11.1\%), consolidation with GGO (5.5\%), and septal lines (5.5\%). LAP (22.2\%), air trapping (5.5\%), and parenchymal band $(5.5 \%)$ were other recorded findings (Table 4). It was determined that CXR was insufficient to detect subpleural nodules, LAPs, and some- times GGO. None of the radiological findings affected duration of hospitalization and existence of hypoxia, but having only nodules affected the need for PICU admission ( $p=0.04)$. Only one patient $(5.5 \%)$ with encephalopathy needed MV and died, so the factors affecting mortality rate and need for MV were not statistically detected. Some of the radiological images are shown in Figure 1.

\section{DISCUSSION}

Influenza virus belongs to the orthomyxovirus family of RNA viruses, and human disease is predominantly caused by types $A$ and $B$ (9). Type $A$ virus is the most virulent and can easily mutate; many subtypes of type A have been identified on the basis of the occurrence of surface glycoproteins, hemagglutinin $(\mathrm{H})$, and neuraminidase $(\mathrm{N})$. The novel H1N1 virus has features of North American and Eurasian swine, avian, and human influenza viruses (10). Most cases of $\mathrm{H} 1 \mathrm{~N} 1$ are mild and self-limited, and less than $10 \%$ of patients require hospitalization. Similar to seasonal influenza, the most common clinical findings at admission are fever, dry cough, sore throat, headache, muscle or joint pain, chills, fatigue, diarrhea, and vomiting, but presentation with dyspnea and respiratory distress is more common in influenza with $\mathrm{H} 1 \mathrm{~N} 1$ virus, and a rapidly progressive pneumonia can develop in children and young to middle-aged adults (10-12). In our study, the main symptoms were also consistent with literature, which are high fever (94\%), cough $(83 \%)$, fatigue (50\%), vomiting (33\%), and difficulty in breathing (33\%).

Interestingly, early in the pandemic, older individuals appeared to be relatively well protected from severe disease from $2009 \mathrm{H} 1 \mathrm{~N} 1$, with most infection-associated hospitalizations occurring in young adults ( $<49$ years of age) and children (13). This contrasts with seasonal influenza epidemics, for which morbidity and mortality are concentrated in the elderly. In addition, to have an underlying disorder is supposed to be a risk factor (14). In our study group, the median age of the patients was 34 (1-216) months, and 12 children (66.6\%) had 1 or more underlying disorders (Table 3 ). Therefore, our study group should be accepted as a high-risk group.

Several papers have described imaging findings in adults with influenza A/H1N1 2009 virus of varying severity (15-20). Findings ranged from unilateral to bilateral predominant peribronchovascular and subpleural GGO with or without associated focal or multifocal areas of consolidation, predominantly in the basal lung zones, resembling organizing pneumonia. The bilateral lower segment and central area are typically involved. Generally, the lung findings first appeared in the lower zones and then rapidly progressed to the middle and upper zones, and the patchy areas progressed to consolidation. Valente et al. (21) reported the reversed halo sign for the first time in H1N1 pneumonia. The reports related to the radiological findings of novel influenza A (H1N1) in children are fewer, but most children demonstrated almost similar radiological findings observed in adults (3-7). Jartti et al. (22) found that the anatomic location of infiltrates was more often peripheral in adults and diffuse among children, and the predominant radiographic findings were consolidation and GGO both adults and children. In our study, GGO (66.6\%) was the leading abnormality, and peripheral dominance was only $5.5 \%$ and diffuse distribution was $66.6 \%$ consistent with this literature.

Mediastinal or paratracheal LAPs were detected in $3(22.2 \%)$ of our patients. Two patients in our study had negative LAP imaging on CXR but positive imaging on CT examination. Li et al. (23) detected LAPs in $6 \%$ of the chest CT scans of their patients, Valente et al. (21) in 12\%, 


\begin{tabular}{|c|c|c|c|c|c|c|c|}
\hline \multirow[b]{2}{*}{ No } & \multirow[b]{2}{*}{ Age } & \multirow[b]{2}{*}{ Gender } & \multirow[b]{2}{*}{ Hx } & \multirow[b]{2}{*}{ MV } & \multirow[b]{2}{*}{ Underlying disease } & \multicolumn{2}{|c|}{ Radiological pattern and distribution } \\
\hline & & & & & & CXR & Thorax CT \\
\hline 1 & 10 & $\mathrm{~F}$ & + & + & Low lgM & $\begin{array}{l}1^{\text {st }} \text { day, GGO, central nodule, } \\
\text { reticulation, unilateral, diffuse }\end{array}$ & None \\
\hline 2 & 13 & M & + & - & None & $1^{\text {st }}$ day, normal & $\begin{array}{l}7^{\text {th }} \text { day, bilateral asymmetric GGO, } \\
\text { peripheral nodule, reticulation, } \\
\text { septal lines, tree-in-bud pattern, } \\
\text { diffuse, middle-lower zone }\end{array}$ \\
\hline 3 & 18 & M & + & - & Tay Sachs, low IgA & None & $\begin{array}{l}6^{\text {th }} \text { day, bilateral symmetric GGO, } \\
\text { peripheral nodule, tree-in-bud pattern, } \\
\text { multifocal, diffuse, middle-lower zone }\end{array}$ \\
\hline 4 & 19 & $\mathrm{~F}$ & - & - & $\begin{array}{l}\text { BPD, malnutrition, } \\
\text { low } \lg G \text { and } \lg A\end{array}$ & $2^{\text {nd }}$ day, normal & None \\
\hline 5 & 37 & M & + & - & VSD, malnutrition & $2^{\text {nd }}$ day, normal & $\begin{array}{c}9^{\text {th }} \text { day, bilateral asymmetric multifocal } \\
\text { diffuse consolidation+GGO, } \\
\text { peripheral nodule, all zones, hilar LAP }\end{array}$ \\
\hline 6 & 5 & $M$ & - & - & Down, VSD & $1^{\text {st }}$ day, normal & None \\
\hline 7 & 1 & $\mathrm{~F}$ & + & - & $\begin{array}{l}\text { Prematurity, physiological } \\
\text { hypogammaglobulinemia }\end{array}$ & $\begin{array}{l}1^{\text {st }} \text { day, bilateral, } \\
\text { symmetric GGO, diffuse, } \\
\text { all zones }\end{array}$ & $\begin{array}{l}1^{\text {st }} \text { day, bilateral, symmetric GGO, } \\
\text { diffuse, all zones, paratracheal LAP, }\end{array}$ \\
\hline 8 & 4 & M & + & - & None & $\begin{array}{l}1^{\text {st }} \text { day, bilateral asymmetric GGO, } \\
\text { reticulation, diffuse, all zones, } \\
\text { air trapping }\end{array}$ & None \\
\hline 9 & 216 & $\mathrm{~F}$ & - & - & $\begin{array}{l}\text { Late onset ADA def., } \\
\text { bronchiectasis, malnutrition }\end{array}$ & None & $\begin{array}{l}1^{\text {st }} \text { day, bilateral, asymmetric, diffuse, } \\
\text { all zones, hilar LAP, bronchial dilatation }\end{array}$ \\
\hline 10 & 86 & $F$ & - & - & $\begin{array}{l}\text { CD3 } \gamma \text { def., operated } \\
\text { autoimmune thyroiditis, } \\
\text { bronchiectasis, }\end{array}$ & $\begin{array}{c}1^{\text {st }} \text { day, bilateral asymmetric, multifocal, } \\
\text { consolidation, reticulation, } \\
\text { middle-lower zone, central lesions }\end{array}$ & None \\
\hline 11 & 122 & $\mathrm{~F}$ & + & - & Hyper lgE synd. & $\begin{array}{l}1^{\text {st }} \text { day, bilateral asymmetric GGO, } \\
\text { diffuse central, middle-lower }\end{array}$ & None \\
\hline 12 & 132 & M & - & - & Bruton disease & $\begin{array}{l}1^{\text {st }} \text { day, bilateral asymmetric, } \\
\text { multifocal GGO, all zones, } \\
\text { reticulation, central predominance }\end{array}$ & None \\
\hline 13 & 189 & $\mathrm{~F}$ & - & - & None & $\begin{array}{l}1^{\text {st }} \text { day, GGO, central nodule, } \\
\text { bilateral asymmetric, diffuse, } \\
\text { middle-lower zones }\end{array}$ & None \\
\hline 14 & 73 & M & - & - & Asthma & $\begin{array}{l}1^{\text {st }} \text { day, GGO, bilateral asymmetric, } \\
\text { reticulation, diffuse, all zones, } \\
\text { central predominance, hilar LAP }\end{array}$ & None \\
\hline 15 & 119 & $M$ & + & - & Bronchiectasis & None & $\begin{array}{c}9^{\text {th }} \text { day, consolidation+GGO, bilateral } \\
\text { asymmetric, multifocal, diffuse, all zones, }\end{array}$ \\
\hline 16 & 31 & $\mathrm{~F}$ & _- & - & None & $1^{\text {st }}$ day, normal & None \\
\hline 17 & 27 & M & - & - & None & $\begin{array}{l}1^{\text {st }} \text { day, bilateral asymmetric GGO, } \\
\text { reticulation, diffuse, all zones, } \\
\text { central predominance }\end{array}$ & $16^{\text {th }}$ day, normal \\
\hline 18 & 58 & $F$ & + & - & $\begin{array}{l}\text { Bronchiolitis obliterans, } \\
\text { epilepsy }\end{array}$ & $1^{\text {st }}$ day, normal & None \\
\hline
\end{tabular}

and Im et al. (7) in 75\%. In the study of Lee et al. (6), abnormal findings were mostly symmetric in pediatric patients with a more severe clinical course, and nodular opacities, reticular opacities, or LAP was not observed in any patient in contrast with our study.
In our study, we determined that CXR was insufficient to detect subpleural nodules, LAPs, and sometimes GGO. Some of our patients did not have any abnormalities on CXR while having on thorax CT. Abbo et al. (24) also reported several patients who were negative 
Table 4. Chest X-ray and computed tomography findings in children with $\mathrm{H} 1 \mathrm{~N} 1$ infection

\begin{tabular}{|c|c|c|}
\hline Pattern of parenchymal lesion & $\mathbf{n}$ & (\%) \\
\hline GGO* only & 12 & $(66.6)$ \\
\hline Consolidation only & 3 & $(16.6)$ \\
\hline Consolidation with GGO* & 1 & $(5.5)$ \\
\hline Nodules & 5 & $(27.7)$ \\
\hline Tree-in-bud pattern & 2 & $(11.1)$ \\
\hline Septal lines & 1 & $(5.5)$ \\
\hline Reticulation & 7 & $(38.8)$ \\
\hline \multicolumn{3}{|l|}{ Location } \\
\hline Central dominant & 5 & $(27.7)$ \\
\hline Peripheral dominant & 1 & $(5.5)$ \\
\hline Random & 8 & $(44.4)$ \\
\hline \multicolumn{3}{|l|}{ Lateralization } \\
\hline Unilateral & 1 & $(5.5)$ \\
\hline Bilateral & 13 & $(72.2)$ \\
\hline Symmetric & 2 & $(11.1)$ \\
\hline Asymmetric & 11 & $(61.1)$ \\
\hline \multicolumn{3}{|l|}{ Affected zone } \\
\hline Middle+lower & 5 & $(27.7)$ \\
\hline All & 9 & $(50)$ \\
\hline \multicolumn{3}{|l|}{ Extent of abnormal opacities } \\
\hline Multifocal & 5 & $(27.7)$ \\
\hline Diffuse & 12 & $(66.6)$ \\
\hline \multicolumn{3}{|l|}{ Associated abnormality } \\
\hline Lymphadenopathy & 4 & $(22.2)$ \\
\hline Air trapping & 1 & $(5.5)$ \\
\hline Parenchymal band & 1 & $(5.5)$ \\
\hline
\end{tabular}

for radiograph but positive for $\mathrm{CT}$. This result can be associated with the explanation that thorax CT is more useful than CXR in showing radiological findings or $\mathrm{H} 1 \mathrm{~N} 1$ influenza radiological findings appear after the first days. Therefore, if a patient with $\mathrm{H} 1 \mathrm{~N} 1$ influenza presents with hypoxia but has negative radiography, a chest CT examination would be deemed useful to detect pneumonia at an early stage.

Prognostic factors for $\mathrm{H} 1 \mathrm{~N} 1$ influenza in children according to the radiological findings are not clear yet. Hypoxia was noted in half the children, and the frequency did not change according to ages in our study group. None of the radiological findings affected the duration of hospitalization and existence of hypoxia, but having only nodules affected the need for PICU admission ( $p=0.04$ ). Im et al. (7) suggested that peribronchial cuffing, air-trapping, and nodules, which were related to small airway disease, are a causative factor of severe dyspnea. Agarwal et al. (15) reported that in patients in more severe

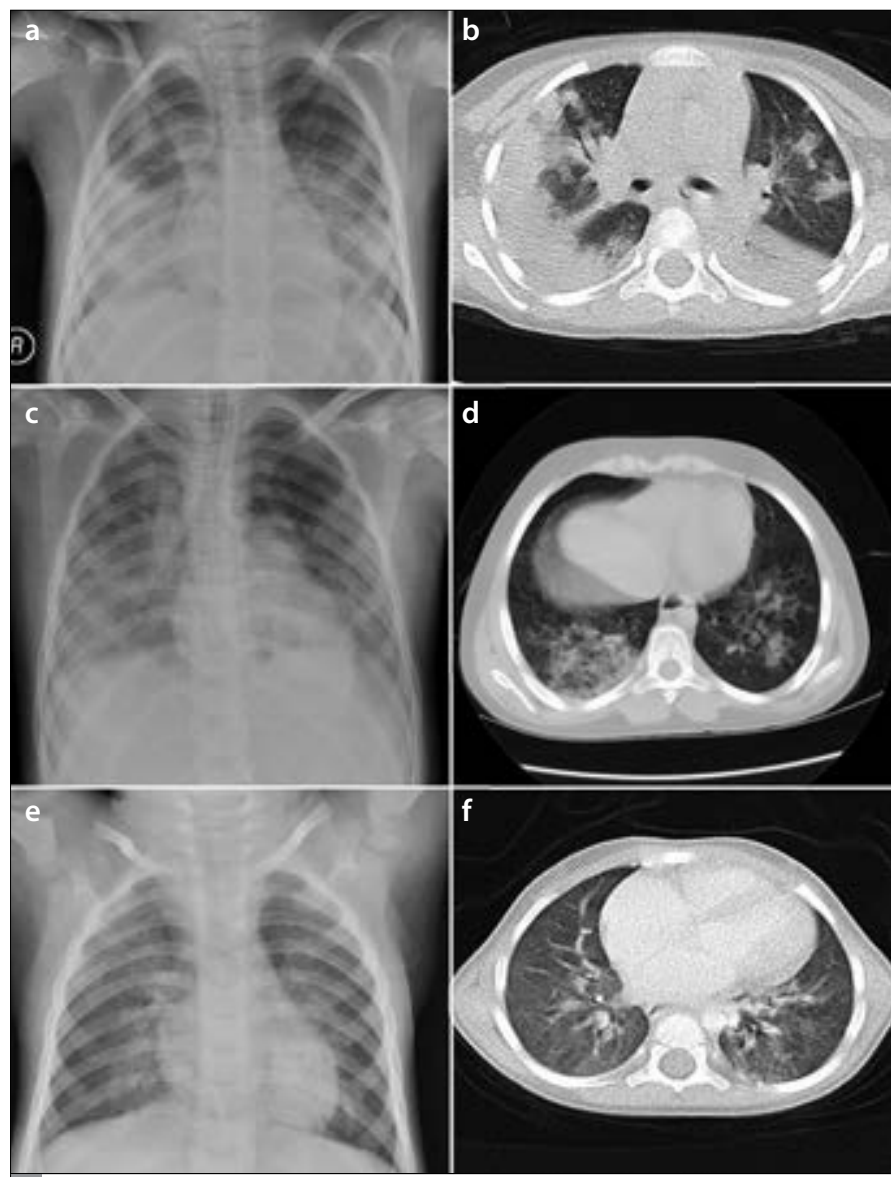

Figure 1. a-f. Example of diffuse consolidation on a chest radiograph obtained 3 days after the onset of symptoms in a 5-year-old female (patient 1) with H1N1 influenza (a). Axial computed tomography (CT) image of patient 1 a day after chest radiograph showing consolidation areas in the peripheral lung areas with lower and middle zone predominance (b). Example of mild ground-glass opacities in the central perihilar areas on chest radiograph obtained 4 days after the onset of symptoms in a 1-year-old boy (patient 2) with H1N1 influenza (c). Axial CT image of patient 2 two days after chest radiograph showing diffuse ground-glass opacities (d). Example of bilateral groundglass appearance on lower zones on a chest radiograph obtained 3 days after the onset of symptoms in an 8 year-old male (patient 3) with H1N1 influenza (e). Axial CT image of patient 3 two days after chest radiograph showing bilateral patchy opacities with lower and middle zone predominance ( $f$ )

stages of infection, the most frequent pattern was bilateral alveolar disease with predominance in the mid-basal lung zones. In the study of Teplisky et al. (5), which included only CXR examinations in 47 patients, consolidation and GGO had a significantly higher frequency in patients who needed more days of oxygen supplement, and initial CXR with lobar consolidation was observed in patients with a greater risk of intensive care unit admission. Valente et al. (21) reported 50 patients with a severe clinical course of novel swine-origin influenza $A(\mathrm{H} 1 \mathrm{~N} 1)$ virus (S-OIV) and found that lesion extent is related to aggressiveness of the illness and that the clinical course is worse in obese patients and that superinfection leads to worsening of clinical conditions. Lopez Delgado et al. (25) found thrombocytopenia as a mortality risk factor. We also found that existence of thrombocytopenia increased the need for PICU admission. 
A rapid progression of the radiological abnormalities and development of acute respiratory distress syndrome (ARDS) can be identified in patients requiring PICU admission $(15,26)$. In one of our patients, while the X-ray was normal at admission, bilateral patchy opacities at basal regions appeared in the thorax CT scan after $4 \mathrm{~h}$ of admission, and ARDS developed after $18 \mathrm{~h}$ of admission.

Although the clinical symptoms disappeared, the radiological recovery can be slow or incomplete in $\mathrm{H} 1 \mathrm{~N} 1$ pneumonia. In the study of $\mathrm{Li}$ et al. (23), the longest follow-up period for CT examinations was approximately 4 weeks after the onset, during which time the $C T$ images were still showing various degrees of residual lesions. Also, one of our patients had GGO on the thorax CT 16 days post-discharge.

This study has several limitations. First, it is a retrospective study with a small number of participants, and it used data from a single institution. Second, we did not compare our results with data of hospitalized adults. Third, some patients did not have both CXR and CT scans, so it was difficult to compare the differences between imagings. Finally, we could not follow-up the patients. Therefore, we could not detect when the pathological findings on radiological imagings resolved.

\section{CONCLUSION}

This study suggests that CT is superior to standard CXRs to show the extent and characterization of the disease and should be the imaging modality of choice in high-risk patients. The most common radiological findings in children with influenza $A(\mathrm{H} 1 \mathrm{~N} 1)$ pneumonia are bilateral, asymmetric GGO with or without associated focal or multifocal areas of consolidation with random distribution. Reticulation, nodules, and LAP may be associated findings. Existence of nodules and thrombocytopenia were found to increase the need for PICU admission. Radiologists should be aware of CXR and CT findings of this viral infection, so that the diagnosis of novel influenza $A(H 1 N 1)$ pneumonia should be promptly considered. Further studies are necessary for clinical assessment of the condition and the corresponding timely management, which will facilitate controlling the infection and decreasing the death rate.

Ethics Committee Approval: Ethics committee approval was received for this study from the ethics committee of Necmettin Erbakan University Meram Medical Faculty.

Informed Consent: Written informed consent was obtained from patients who participated in this study.

Peer-review: Externally peer-reviewed.

Author contributions: Concept - S.P.; Design - B.G.; Supervision - K.Ö.; Resource - S.P., K.Ö.; Materials - S.P., K.Ö.; Data Collection and/or Processing - S.P., B.G.; Analysis and/or Interpretation - S.P., B.G.; Literature Search - S.P., B.G.; Writing - B.G.; Critical Reviews - I.R.

Conflict of Interest: No conflict of interest was declared by the authors.

Financial Disclosure: The authors declared that this study has received no financial support.

\section{REFERENCES}

1. Centers for Disease Control and Prevention (CDC). Outbreak of swine-origin influenza A (H1N1) virus infection - Mexico, March-April 2009. MMWR Morb Mortal Wkly Rep 2009; 58: 467-70.

2. The Ministry of Health of Turkey. Pandemic influenza A(H1N1) bulletin. Available from:http://www.grip.gov.tr/index.php?option=com_content\&view=ar- ticle\&id=854:19012010-tarihli-acklama-saat-1800-\&catid=112:haberler\&ltemid=539 (accessed 19 January 2010).

3. Mori T, Morii M, Terada K, Wada Y, Kuroiwa Y, Hotsubo T, et al. Clinical characteristics and computed tomography findings in children with 2009 pandemic influenza A (H1N1) viral pneumonia. Scand J Infect Dis 2011; 43: 47-54. [CrossRef]

4. Guo W, Wang J, Sheng M, Zhou M, Fang L. Radiological findings in 210 paediatric patients with viral pneumonia: a retrospective case study. $\mathrm{Br} J$ Radiol 2012; 85: 1385-9. [CrossRef]

5. Teplisky DJ, Galeano M, Tedesco EV, Gonseski CV, Sánchez Salinas PA, Blanco C, et al. Influenza A H1N1 respiratory infection: radiologic findings and correlation with clinical outcome in pediatric inpatients. A pediatric hospital experience. Arch Argent Pediatr 2011; 109: 525-9. [CrossRef]

6. Lee EY, McAdam AJ, Chaudry G, Fishman MP, Zurakowski D, Boiselle PM. Swine-origin influenza a (H1N1) viral infection in children: initial chest radiographic findings. Radiology 2010; 254: 934-41. [CrossRef]

7. Im SA, Kim HL, Yoon JS, Kang JH, Lee JS, Chun HJ. Swine-origin influenza A viral (H1N1) infection in children: chest computed tomography findings. Jpn J Radiol 2011; 29: 707-11. [CrossRef]

8. World Health Organization Website. Global alert and response: CDC protocol of real-time (RT) PCR for influenza A (H1N1) html. [cited 2009 April 30]. Available from: URL:http://www.who.int/csr/resources/publications/swineflu/realtimeptpcr/en/index.html

9. Garcia-Garcia J, Ramos C. Influenza, an existing public health problem. Salud Publica Mex 2006; 48: 244-67.

10. Novel Swine-Origin Influenza A (H1N1) Virus Investigation Team, Dawood FS, Jain S, Finelli L, Shaw MW, Lindstrom S, et al. Emergence of a novel swine-origin influenza A (H1N1) virus in humans. N Engl J Med 2009; 360: 2605-15. [CrossRef]

11. Bettinger JA, Sauvé LJ, Scheifele DW, Moore D, Vaudry W, Tran D, et al. Pandemic influenza in Canadian children: a summary of hospitalized pediatric cases. Vaccine 2010; 28: 3180-4. [CrossRef]

12. Çiftçi E, Tuygun N, Özdemir H, Tezer H, Şensoy G, Devrim I, et al. Clinical and epidemiological features of Turkish children with 2009 pandemic influenza A (H1N1) infection: experience from multiple tertiary paediatric centres in Turkey. Scand J Infect Dis 2011; 43: 923-9. [CrossRef]

13. Jain S, Kamimoto L, Bramley AM, Schmitz AM, Benoit SR, Louie J, et al. Hospitalized patients with $2009 \mathrm{H} 1 \mathrm{~N} 1$ influenza in the United States, April-June 2009. N Engl J Med 2009; 361: 1935-44. [CrossRef]

14. Thompson WW, Shay DK, Weintraub E, Brammer L, Bridges CB, Cox NJ, et al. Influenza-associated hospitalizations in the United States. JAMA 2004; 292: 1333-40. [CrossRef]

15. Agarwal PP, Cinti S, Kazerooni EA. Chest radiographic and CT findings in novel swine-origin influenza A (H1N1) virus (S-OIV) infection. AJR Am J Roentgenol 2009; 193: 1488-93. [CrossRef]

16. Karadeli E, Koç Z, Ulusan S, Erbay G, Demiroglu YZ, Sen N. Chest radiography and CT findings in patients with the 2009 pandemic (H1N1) influenza. Diagn Interv Radiol 2011; 17: 216-22.

17. Marchiori E, Zanetti G, Hochhegger B, Rodrigues RS, Fontes CA, Nobre $L F$, et al. High-resolution computed tomography findings from adult patients with influenza A (H1N1) virus associated pneumonia. Eur J Radiol 2009; 74: 93-8. [CrossRef]

18. Ajlan AM, Quiney B, Nicolaou S, Müller NL. Swine-origin influenza A (H1N1) viral infection: radiographic and CT findings. AJR Am J Roentgenol 2009; 193: 1494-9. [CrossRef]

19. Lee CW, Seo JB, Song JW, Lee HJ, Lee JS, Kim MY, et al. Pulmonary complication of novel influenza A (H1N1) infection: imaging features in two patients. Korean J Radiol 2009; 10: 531-4. [CrossRef]

20. Mollura DJ, Asnis DS, Crupi RS, Conetta R, Feigin DS, Bray M, et al. Imaging findings in a fatal case of pandemic swine-origin influenza $A$ (H1N1). AJR Am J Roentgenol 2009; 193: 1500-3. [CrossRef]

21. Valent eT, Lassandro F, Marino M, Squillante F, Aliperta M, Muto R. H1N1 pneumonia: our experience in 50 patients with a severe clinical course of novel swine-origin influenza A (H1N1) virus (S-OIV). Radiol Med 2012; 117: 165-84. [CrossRef] 
22. Jartti A, Rauvala E, Kauma H, Renko M, Kunnari M, Syrjälä H. Chest imaging findings in hospitalized patients with H1N1 influenza. Acta Radiol 2011; 52: 297-304. [CrossRef]

23. Li M, Zhu JB, Chen GQ, Yang WY, Tao C, Wang XH. Influenza A (H1N1) pneumonia: an analysis of 63 cases by chest CT. Chin Med J (Engl) 2011; 124: 2669-73.

24. Abbo L, Quartin A, Morris MI, Saigal G, Ariza-Heredia E, Mariani P, et al. Pulmonary imaging of pandemic influenza $\mathrm{H} 1 \mathrm{~N} 1$ infection: relationship between clinical presentation and disease burden on chest radiography and CT. Br J Radiol 2010; 83: 645-51. [CrossRef]

25. Lopez-Delgado JC, Rovira A, Esteve F, Rico N, Manez Mendiluce R, Ballús Noguera J, et al. Thrombocytopenia as a mortality risk factor in acute respiratory failure in H1N1 influenza. Swiss Med Wkly 2013; 143: w13788.

26. Pinilla I, de Gracia MM, Quintana-Díaz M, Figueira JC. Radiological prognostic factors in patients with pandemic H1N1 ( $p H 1 N 1$ ) infection requiring hospital admission. Emerg Radiol 2011; 18: 313-9. [CrossRef] 